Conrad P. Waligorski, Editor

\title{
American Politics
}

Ketcham, Ralph. Framed for Posterity: The Enduring Philosophy of the Constitution. Lawrence, KS: University of Kansas Press, 1993. 195 pp. (\$25 cloth).

In Framed for Posterity: The Enduring Philosophy of the Constitution, Ralph Ketcham has written a book designed to shift the focus of the debates about the Constitution. He discusses the framers' intentions without being an originalist. He writes eloquently about the Bill of Rights without championing an individualistic, private view of politics. He considers the "higher law" of the Constitution without being a reactionary. In doing all these things, Ketcham does the framers the honor of taking the document and the thought of the founding seriously, without engaging in useless homage.

The central lesson that Ketcham wants to teach is that the founders were strong believers in active, energetic government. The Constitution is not designed simply to ward off the dangers of necessary, evil government. Rather, America was founded by men who attempted to combine the ancient belief in politics as a positive good (recall Aristotle's injunction that the good life is found in a political life) with the modern concern to maintain the freedom of the individual (Locke and Algernon Sidney come to mind). Ketcham's most important contribution is to emphasize the former goal, without losing sight of the obvious importance of the latter. In his careful discussion of the writings of Madison and Jefferson, Ketcham demonstrates that the belief in republicanism and the public good were never lost in the debates that swirled about the ratification of the Constitution.

Ketcham's work becomes all the more important if we reflect on the state of Constitutional interpretation in recent years. Ketcham's concern for a public good has been lost on both the "right" and "left" of the political spectrum. The "right" fears government as tyrannical and abusive of property, so much so that, in the past twelve years, we have witnessed a virtual worship of the market as a source of both wealth and freedom. The recent rise of $\mathrm{H}$. Ross Pe1 tt, and the desire for an entrepreneur as president, is only a variation of this phenomenon. The "left," on the other hand, is devoted to the Constitution as a source of rights to privacy and protection from an intrusive, moralizing government. While neither side's apprehen- 
sions are baseless, Ketcham urgently asks us to consider: what happened to the "public good"? Good government only can exist with responsible citizens devoted to some principle outside the individual's existence. If all are critical of government, the system will not work. Madison assumed a robust government that would engage the trust and confidence of Americans.

Ketcham does excellent work in showing how the four great principles of the time ("republicanism," "liberty," "the public good," and "federalism") were shared by most of the political actors of the era. The differences, according to the author, were only in degree of support: i.e., some were stronger believers in state rights as opposed to the powers of the national government. However, both sides believed in a vigorous public life, with an active, educated people. While this is certainly true, it downplays significant differences of opinion. The Anti-federalists surely believed in a public good connected to good government; however, their opposition to the national government was also based on a very real fear of the large republic being unresponsive to the citizens it was meant to serve. Ketcham is well aware of these differences of opinion, but his emphasis on what he sees as the greater similarities slights the very real differences. In this regard, this book would be extremely valuable if read in conjunction with Herbert Storing's What the Anti-Federalist Were For. Together, these two books provide a wonderful account of the debates of the 1780 s and connect to the troubled life of contemporary Constitutional debates.

The crowning moment of Framed for Posterity is in the discussion of Justice Frankfurter's dissent in West Virginia $v$. Barnette (the second of the flag salute cases.) While Ketcham is sympathetic to the claims of the Jehovah's Witnesses to religious freedom, he regards the question of democracy as the central issue. What is the health of a democracy if we need a Supreme Court to lecture to the people about right and rights? The public good cannot be maintained by philosopher kings or justices. The dignity of the Constitution must be founded in the dignity of the citizens of the United States; without a people committed to the regime, the decisions of the courts, and the Constitution, depend on enforcement if they are to be more than "parchment barriers." And, as the Anti-federalists warned, to the extent that a government depends on enforcement it ceases to be republican. The rights protected by the Constitution are parts of a whole, useful only if the citizens of the country believe in each other and the common good. Ketcham deserves our thanks for reminding us of that truth. 
Calvin R. Ledbetter, Jr. Carpenter From Conway: George Washington Donaghey as Governor of Arkansas, 1909-1913. Fayetteville, AR: University of Arkansas Press, 1993. xvii, 272 pp. ( $\$ 22$ cloth).

Calvin Ledbetter argues that "in the South during the Progressive period, there were ... two traditions fighting for acceptability-the agrarian Populist tradition versus the Progressive tradition" (p. 6). Within Arkansas, he believes that the first was exemplified by Jeff Davis, the flamboyant Democratic politician who served as the state's governor from 1901 to 1907 and subsequently as United States Senator until his death in 1913. The latter tradition (the one with which Ledbetter identifies and sympathizes) was well represented, he cogently maintains, by George Washington Donaghey, governor of Arkansas from 1909 to 1913 and the subject of Ledbetter's biography.

Summarizing the Populist tradition and its political agenda, Ledbetter acknowledges that the Populists wanted to adopt a graduated income tax, nationalize the railways and the telegraph lines, smash the trusts, coin silver at the ratio of sixteen to one with gold, and enact the subtreasury plan. And yet, in what may strike some readers as at least a partial non sequitur, he concludes that "The Populist programs still spoke primarily for a ruralbased, antitrust tradition that had strong overtones of localism and decentralized government. In fact, many Populists had serious reservations about an active role for government except to break up or regulate the trusts" (p. 3).

Here, Ledbetter seems unaware of the social and financial implications of some Populist proposals, especially the subtreasury plan. The plan, had it been adopted, would have caused massive inflation, bringing about an unprecedented transfer of capital from creditors to debtors and from the industrial to the agricultural sector of the American economy, fundamentally redistributing the nation's wealth.

In his characterization of Populism, Ledbetter may have been influenced indirectly by Richard Hofstadter and other historians of the 1950s who sometimes portrayed the Populists as agrarian primitives lashing out irrationally against modernism. (Regrettably, recent investigations of Populism go unmentioned; in particular, one searches in vain for any reference to Lawrence Goodwyn.) To a degree, though, his assessment of Populism also clearly derives from his identification of the Populist tradition in Arkansas with Jeff Davis. It is worth remembering, however, that Davis was never a Populist. As a young man, he actively campaigned for the local Democracy against the Brothers of Freedom in 1884 and against the Union Labor Party in 1888. Much later, well after Populism had expired, he 
lamented his earlier opposition to the third-party insurgents, and in truth there was a tinge of authentic agrarian radicalism in the Davis movement.

Davis's reluctance at times to embrace an active role for government may have derived more from his traditional Democratic roots and Redeemer heritage than from any exposure to Populism. A case in point might be Davis's opposition to a state-owned railroad. Ledbetter, after observing that the Populists advocated government-owned railways, cites Davis's opposition to them as an example of his adherence to "the Populist . . . antigovernment tradition" (p. 9). This internal contradiction would have been made even more glaring had he not omitted a crucial fact: that the chief proponent of state-owned railroads in Arkansas was J.O.A. Bush, a Populist Party state senator.

If Ledbetter's analysis of Populism sometimes seems off the mark, his description of progressivism is right on target. He notes that the progressives were not a "unified political force" but rather "a loosely connected group of people who frequently differed on issues" (p. 3). Progressive leaders came from a variety of backgrounds, but at heart their movement was urban and middle class in nature-direct involvement in progressive crusades by such groups as tenant farmers, recent immigrants, and blacks usually was not solicited or welcomed. In many ways simply enlightened conservatives, the progressives accepted capitalism, industrialization and the existing power arrangements of contemporary American society. Their overarching goal "was to retain the benefits of an industrialized society while alleviating many of the excesses" (p. 3). They also aspired to end corruption and promote efficiency in government and to make government operations more "businesslike."

George Donaghey was in many respects a quintessential progressive. Although born and raised in the country, where he had to overcome both an alcoholic father and grinding rural privation, early in life he moved to Conway, Arkansas, where he became a prominent and wealthy entrepreneur and building contractor. His concern over perceived corruption and inefficiency in the construction of Arkansas's new state capitol induced him to enter the political arena and first run for governor in 1908.

Serving two terms as Arkansas's chief executive, Donaghey promoted not only the building of the new Capitol but a variety of other measures, including a State Board of Health, a tuberculosis sanitarium, four new agricultural high schools, and a State Board of Education. He also successfully campaigned for the introduction of the initiative and referendum, making Arkansas the only Southern state to embrace this progressive reform. Through a mass pardoning of state prisoners during his next to last month in office, he played a key role in bringing Arkansas's 
notorious convict-lease system to an end. He also tried, though with less success, to revamp the state's archaic and inequitable property-assessment and tax system.

Upon leaving office, Donaghey continued to be involved in a wide variety of civic affairs and worthy public causes. Childless, toward the end of his life he and his wife Louvenia bequeathed most of their estate to Little Rock Junior College, the forerunner of Ledbetter's home institution, the University of Arkansas at Little Rock.

It is impossible to go away from Ledbetter's stimulating and sympathetic biography without having developed genuine affection and respect for its subject. George Washington Donaghey, one is convinced, was a good and decent man. He never really changed, indeed, never tried to change, the essential order of things. One of the most revealing statistics in Ledbetter's book shows that in 1890 , at the beginning of the progressive era, one third of Arkansas' farmers were tenants or sharecroppers; by 1920 , toward the end of progressivism, the percentage had risen to over one half. But if most Arkansans remained mired in poverty and wretchedness, Donaghey had helped in a limited way to ameliorate their suffering. Few would disagree with the epitaph that was carved on his burial marker in Little Rock's Roselawn Memorial Park: "He left the world better than he found it."

John William Graves

Henderson State University

Moore, John L., ed. Congressional Ethics: History, Facts, and Controversy. Washington, DC: Congressional Quarterly, 1992. 189 pp. (\$16.95 paper).

Cohn, Mary W., ed. Congressional Pay and Perquisites: History, Facts, and Controversy. Washington, DC: Congressional Quarterly, 1992. 96 pp. ( $\$ 16.95$ paper).

Cohn, Mary W., ed. Congressional Campaign Finances: History, Facts and Controversy. Washington, DC: Congressional Quarterly, 1992. 103 pp. (\$16.95 paper).

It is hard to imagine three more timely books on Congress than the recently issued volumes listed above. If a prize were to be awarded for the most reviled American institution, Congress would surely be a serious contender for the grand prize. During the last four years, we have witnessed the resignation, in the face of corruption charges, of House Speaker Jim Wright 
and Majority Whip Tony Coelho. The influence of campaign contributions on congressional actions has been widely chronicled and dramatically illustrated by the Keating Five scandal. Finally, the congressional pay raise of 1991 and the House Bank scandal have placed Congress on the defensive about the privileges of office that its members have traditionally enjoyed.

These books on Congress might best be classified as reference works. Though editors are listed for each volume, no authors are credited for individual chapters. None of these books are standard academic works replete with references to extant literature in the field. (Each book does contain footnotes and a selected bibliography.) Nor do they contain hypotheses that the authors seek to validate with new empirical evidence. Each book is full of facts on its respective topic and there are short case studies of particularly noteworthy people and events.

Congressional Ethics: History, Facts and Controversy is the longest of the three volumes. It contains separate chapters on expulsion, censure/ reprimand/denouncement, and loss of committee or sub-committee chairthe punishments that Congress can inflict upon errant members. Each chapter contains short case studies that detail memorable cases in Congressional ethics violations or alleged violations. For example, the censure of Senator Joseph McCarthy, the resignation of Speaker Jim Wright, and the denunciation of Senator David Durenberger are depicted in vignettes of a few pages each.

The volume on ethics also contains chapters on the major types of Congressional ethics violations: accepting favors, money, or gifts from lobbyists; outright bribery, such as that which occurred in the Abscam scandal; improper conduct related to alcohol or sex; and abuse or misuse of staff. Each chapter contains a short introduction to the relevant issue and then proceeds to describe the many members of Congress who have been involved in scandals in the last three decades. (The picture of former Arkansas Congressman Wilbur Mills on the stage of a Boston nightclub with the fully clothed stripper Fanne Fox is downright risque by Congressional Quarterly standards.) The book concludes with a chapter on reform measures enacted in the past 30 years.

Congressional Pay and Perquisites: History, Facts, and Controversy is a short book that begins with a chapter on the history of controversies surrounding congressional salaries. Other chapters provide concise descriptions of congressional perks, including the franking privilege, foreign travel, office accounts, and staff. It is unfortunate that this volume was released just before the House bank scandal became front page news across the country. The relative obscurity of the bank and its generous overdraft policy is demonstrated by the fact that it is omitted from a list of privileges accorded 
members that includes the House gym, barber shops and beauty salons, and special parking places at Washington area airports. The bank scandal is mentioned in the volume on congressional ethics.

Congressional Campaign Finances: History, Facts, and Controversy contains several useful chapters that include good surveys of the role of money in congressional elections, campaign finance reforms enacted in the 1970 s, and recent reform proposals. There is also a valuable appendix that contains excerpts from the 1971 Election Campaign Act and its subsequent amendments. In addition, there is a lengthy extract from the Supreme Court's landmark 1976 case Buckley v. Valeo.

The books reviewed here are full of interesting information on Congress. Those seeking scholarly interpretations of Congress will have to look elsewhere. It is doubtful if reference works such as these will be widely adopted for classroom use. However, every library should have a copy of each of these books.

Donald Beachler Ithaca College

Nelson, Garrison, with Clark H. Bensen. Committees in the U.S. Congress, 1947-1992: Committee Jurisdictions and Member Rosters (Volume 1). Washington, DC: CQ Press, 1993. 1015 pp. (\$225 cloth). Kravitz, Walter. Congressional Quarterly's American Congressional Dictionary. Washington, DC: CQ Press, 1993. 305 pp. (\$32.95 cloth).

While these works provide easy access to information on the U.S. Congress, they vary widely in the types of information they contain. Nelson's volume presents a wealth of empirical data on congressional committees. Kravitz's book is a quick-reference glossary of congressional terms.

Professor Nelson's is an extremely ambitious project. His wellorganized volume is the first of a projected six-volume set that will document the committee assignments of all members of the U.S. Congress from the 1st Congress (1789-1790) through the 102nd Congress (19911992). The data contained in the initial volume begin with the 80th congress (1947-1948), the first one to convene following the Legislative Reorganization Act of 1946, and extend through the 102nd Congress. Most political scientists would agree that data collection is the least stimulating phase of empirical research projects. Professor Nelson and his many assistants have undoubtedly completed this phase of research (or portion of it) for a number 
of future projects. For this reason alone, several scholars will be grateful to Professor Nelson and his comrades.

Parts I and III present rosters and supplemental information, in alphabetical order by committee name, for each Senate and House standing committee. Documentation of each standing committee roster is preceded by a description of the jurisdictional changes of each committee over time. The committee rosters and supporting material include the following for each Congress: state, party, and committee rank of each majority and minority member, years of service in the chamber, years of service on the committee, changes in the majority and minority committee membership, and departures from the chamber. When applicable, the roster indicates whether a member is in a $1 \mathrm{st}, 2 \mathrm{nd}$, or $3 \mathrm{rd}$ period of service on the committee. Parts II and IV present identical information on Senate and House Select and Special Committees-an area often neglected by scholars; part V presents the same information on Joint Committees in the Congress.

Professor Nelson's research on leadership recruitment and selection in the U.S. House provided the background and inspiration for this project. The data included in this volume and the five forthcoming ones are likely to inspire additional empirical work on congressional committees. The data can be used to test not only theories relating specifically to leadership recruitment, selection, and seniority, but to related institutional features such as specialization, retirement, careerism, and so forth. Other interesting questions can be tested with these data, such as "Do certain jurisdictional changes impact the nature and character of committee memberships?" or "Are there patterns of membership mobility between committees or between certain types of committees?"

Extensive research has been conducted on congressional committees using cross-sectional research designs. The convenience provided by this new data set may inspire additional projects using time series designs. This is especially encouraging because concepts and terms such as seniority, specialization, retirement patterns, mobility between committees, and the like may produce different trends during different historical periods. Thus, hypotheses related to these terms are best studied over time. Given the promise for theorizing about and identifying different trends, it is a bit disappointing that all six volumes are not available right now. Because of the overwhelming nature of the project perhaps this is too much to ask. Since time series studies are in particularly short supply for the period from the 1st through 79th Congresses, many scholars, myself included, will eagerly await the publication of additional volumes in the set.

The preface to the volume provides a short history of the development of the congressional committee system. Some may find the chronology to be 
a useful supplement to undergraduate and graduate lecture material. Since the index includes both member and committee names, it is relatively easy to access the information contained in Nelson's volume.

The focus of Kravitz's glossary is on terms in current use in the Congress. It includes entries on legislative process, congressional procedures, committees, formal leadership posts, organization, staff, and the like. The glossary should prove enormously useful to government practitioners and observers who have day-to-day contact with those in Congress, as well as to other individuals who need to have a command of legislative procedures. Members of Congress, congressional and executive staff, journalists, and interest group organizations and their lobbyists will find this work indispensable because of its extensive coverage of parliamentary and other technical terms. A small number of scholars, especially those who teach and conduct research in the area of legislative process, will also find the material useful.

The intent of this work is not to provide an exhaustive or even abbreviated list of concepts employed in the contemporary scholarly literature on the Congress. Scholars hoping to find definitions and history of important behavioral concepts such as incumbency advantage, norms, representation, party voting, divided government, or rational choice, to mention only a few, will be disappointed. One would expect coverage of such terms in a work entitled American Congressional Dictionary.

Three other features of the dictionary deserve mention. The extensive cross-referencing makes terms easily accessible. Kravitz also provides the reader with useful across-chamber comparisons of House and Senate rules, procedures, and terminology. Finally, Kravitz provides interesting historical background on several terms; however, the criteria for choosing when to provide historical background (and when not to) are unclear and never presented by the author. Some sort of statement of the decision rule would be appreciated.

Both Nelson's and Kravitz's works are needed, but they address very different needs. Nelson's collection of committee data will prove most useful to political scientists seeking to test hypotheses relating to Congress and the executive branch. The American Congressional Dictionary is likely to become standard reference fare for government practitioners, interest group organizations, journalists, and other political pundits. 


\section{Pomper, Gerald M., F. Christopher Arterton, Ross K. Baker, Walter} Dean Burnham, Kathleen A. Frankovic, Marjorie Randon Hershey, and Wilson Carey McWilliams. The Election of 1992: Reports and Interpretations. Chatham, NJ: Chatham House Publishers, 1993. 240 pp. (\$25.00 cloth, \$16.95 paper).

Beginning with the 1976 election, Gerald Pomper and his colleagues have provided our discipline with authoritative analyses of our quadrennial national elections. Readers are cautioned not to assume that this latest in a series of case studies lacks any theoretical base. Pomper's opening chapter on "The Legacy of George Bush" goes beyond the conventional wisdom of Bush's tragedy of being outshined by the charismatic Reagan to provide a fascinating theoretical and historical framework for what he terms the "thirdterm understudies." Each of these Presidents generally followed charismatic Presidents rated by historians as "Great Presidents" who enacted distinctive and dramatic public policies. Each faced numerous obstacles to their reelections, such as intraparty splits, economic and foreign setbacks, and social unrest, and only one was re-elected. While somewhat subjective, this theoretical framework should encourage other researchers to pursue a more comprehensive and "scientific" test of its major components. Reflecting his statistical as well as theoretical prowess, Pomper demonstrates how these third-term understudies suffered a massive interelection vote loss compared to other incumbent Presidents.

The primary strength of this volume is its thorough chronicling of the presidential campaign, complete with essential documentation. In Baker's study of "The Presidential Nominations, " for example, readers are provided with each party's primary vote and delegate totals in each state, as well as the final Democratic convention vote. Exit polls illustrate the economic protest votes against Bush in the early New Hampshire primary, presaging the President's "Pyrrhic Victory," as well as Clinton's lower socioeconomic status base within the Democratic party, heralding the traditionally Democratic tax-and-spend approach of his first months as President.

Arterton's chapter on campaign strategies and tactics, which incorporates campaign technology and the new talk-show format, reveals how the Clinton team's quick responses to Bush's attacks contributed to the President's failure to divert public attention from the economy. Yet, like most campaign studies, it leaves one wondering whether the campaign actually exerted any significant effect on voters, or whether the 53-47 percent twoparty vote split could have been predicted on the basis of such longer-term factors as the public's partisan identification ties and overall discontent. 
Frankovic's public opinion chapter thoroughly charts the rise of the candidates' name visibility and fluctuations in their popularity, and links such changes with campaign events. Whereas Clinton successfully united Democrats at this convention, the Bush camp's convention attacks on Clinton repelled voters who preferred solutions to problems. The repetitiveness of the book's theme of the importance of the economy becomes evident by this time. Frankovic seeks to rebut the conventional wisdom that voters don't really change their minds during a campaign, yet Clinton's popularity lead over Bush on election day was quite similar to where it stood two months earlier. She also overstates the argument that new and popular candidates increased voter interest and turnout, since her tables show voter satisfaction with the choices was essentially similar to 1980 and 1984 , and all three candidates in the last week of the campaign were regarded as more "unfavorable" than "favorable."

Pomper's presidential election results chapter expertly documents the issues, social groups, and states that contributed to Clinton's victory. Particularly interesting is the persistence since 1976 of the southern and the western Republican bases versus the northeastern, upper midwestern and northwestern Democratic bases. Pomper's statistical treatment of the issues and personal qualities affecting the vote demonstrates that Clinton's edge over Bush was highest on "bringing change," the economy and jobs, and health care, emphasizing his bread-and butter mandate rather than the social issue agenda (pro-choice, gay rights) that was pursued in his first days in office. A visually-appealing pie chart provides a wealth of information about 1988-1992 vote switching (albeit based on distorted voter recall data).

Hershey's Congressional elections chapter is interesting, given such special circumstances as redistricting, institutional scandals, the term limit movement, and presidential campaigning against congressional opponents. A special variant of the conventional wisdom that voters love their Congress-member but hate the Congress is voter approval of term limit initiatives while re-electing their incumbents. Hershey also finds a direct relationship between number of bank overdrafts and voluntary and involuntary departure from Congress. McWilliams' wrap up chapter on the election's meaning provides a thorough integration of the 1992 election results into the scholarly literature, although excessive footnoting (151) detracts from readability.

While not a major theoretical or methodological breakthrough, Pomper et al.'s The Election of 1992 is an indispensable volume on a fascinating and unique period in U.S. electoral history. It is especially valuable as a supplemental text in such American Politics undergraduate courses as campaign politics, electoral politics, political behavior, and political parties, where it 
ably illustrates important theoretical propositions from the literature with this most recent electoral cycle.

Stephen D. Shaffer Mississippi State University

Tate, Katherine. From Protest To Politics: The New Black Voters in American Politics. Cambridge: Harvard University Press, 1993. 221 pp. (\$32.50 cloth)

This work focuses on the Black electorate and Black political behavior in the 1980s and beyond. Tate's analysis of the Black electorate attempts to answer a number of questions related to conventional and protest politics, divided into eight chapters with the opening chapter focusing on the new Black voter, the new Black politics, and the meaning of Jesse Jackson's presidential campaigns. The new Black voter is characterized by increased registration rates, insignificant differences in voter turnout between Blacks and Whites controlling for socioeconomic status, the impact of victorious Black mayors on Black political efficacy, voter mobilization and backlash against Reaganomics, which disproportionately affected Black Americans, and the windfalls from Jesse Jackson's presidential bids in 1984 and 1988 (p. 8). Tate's work also addresses another, more provocative thesis related to whether the new Black politics can be considered the second stage of the civil rights movement, i.e., "a continuation of the Black protest movement, which most analysts claim ended in 1972" (p. 15).

The following chapters examine race, class, Black policy views, Black electoral participation, and Black voting and turnout in the 1984 and 1988 presidential primaries and elections. The latter part of the book explores the concept of Black power and the re-emergence of Black nationalism, whether Black electoral politics is group-oriented or a movement, and Black alternatives to voting.

Social stratification has increased among Black Americans since the Civil Rights movement of the sixties. These divisions are reflected in the emergence of an underclass, prolonged unemployment, and a larger Black middle class. These divisions have impacted racial identity and support for public policies. Black support for race-specific programs has declined over the last 20 years, and middle- and upper-class Blacks have weaker racial identities than the poor and working classes. Black conservatism has grown since the seventies, although only about ten percent of Blacks could be characterized as true economic conservatives. Blacks with strong racial 
identities are liberals, although evidence suggests that such liberalism does not extend to radical redistributionist views of wealth between rich and poor (p. 49).

Jesse Jackson's presidential bids provided Blacks with additional options, including independent voting and the possibility of a third party, according to Tate. Black identification and support for the Republican party in the future is dismissed for a number of reasons-Blacks are too liberal, the GOP is too conservative on civil rights and race, and Black support for the GOP was at an all-time low (below 10 percent) for Goldwater in 1964 and Reagan in 1980 (p. 72).

Lower-income Blacks with less education vote less than more affluent Blacks with a college education, confirming previous studies. Tate refutes the notion that the Black church is anti-political and deters political participation. Most Blacks who participate in politics and vote are churchgoers. The author states that "The surge in the number of Black candidates running for office is the single most impressive development in the new stage of Black politics" (p. 103). Consequently, Black participation is higher when a Black candidate runs for office. For this reason, Tate cautions, Black candidacies as a political resource have limitations because, among other factors, fewer Blacks are winning office annually and are running for office for the first time in majority-Black districts.

Could Black nonvoting in the 1988 presidential election be considered strategic voting, since strategic voting means maximizing the impact of a collective vote? This question surfaces in the context of the decline of Black voter participation in the 1988 presidential election, in which it peaked at 55.8 percent in 1984 and dropped off to 51.5 percent in the 1988 presidential election. Many Jackson supporters chose not to vote in the 1988 election, thus denying themselves an opportunity for political representation. Whatever the case, Tate notes that numerous surveys reveal that a majority of Black and White Americans feel that America is not ready to elect a Black president (p. 150). This should not be confused with the question oftasked of whites about whether they would vote for a Black for president, to which a plurality of them answer in the affirmative.

Near the end of the work, Tate describes how the Black power movement contributed to the notion of Black political independence, the failure of Black elected officials to adopt it, and Black identity with Black nationalism, a trend that is on the increase. Black nationalism, the author notes, may be a threat to Black elected officials, since it is on the increase as the result of political alienation toward the status quo. While Black power facilitated the switch from protest to electoral politics, it now is challenging mainstream Black elected officials who depend upon white voter support. Tate 
concludes her work with a discussion about Black electoral politics and beyond, examining the options for third party and protest politics while noting that Black political participation is on the decline and will probably continue in that direction.

While some of the arguments made in this book are old and shed no new light, Tate's work makes a timely and significant contribution to the literature on Black politics. She presents thought-provoking arguments about the direction of Black politics in light of current data on Black voting behavior and political attitudes. The focus on Black power and the resurgence of Black nationalism, combined with a discussion of more conventional policies, provides interesting insights and perspectives regarding the future. Although the framework for her study is not novel, political scientists and professors who teach in the area of Black politics will want this book in their library.

Mfanya Tryman Mississippi State University

Watson, Richard A. Presidential Vetoes and Public Policy. Lawrence, KS: University Press of Kansas, 1993. 212 pp. ( $\$ 25.00$ cloth).

This publication when coupled with the only previous books on the subject-Carlton Jackson's Presidential Vetoes, 1792-1945 (University of Georgia Press, 1967) and more recently Robert J. Spitzer's The Presidential Veto: Touchstone of the American Presidency (State University of New York, 1988)-means that any scholar who wishes to access this corpus of research need not look beyond these three volumes.

Presidential Vetoes and Public Policy has seven chapters. Chapter 1 overviews the Roman and English origins of the veto, its establishment here during the Colonial and Founding eras, and its development during the early years of the Republic, in the Jacksonian and pre-Civil War eras, and up to the 1930s. Chapter 2 proceeds with a systematic analysis of vetoes by the modern presidents from Franklin D. Roosevelt through Carter. Why equal coverage was not given to Reagan, let alone Bush, is a bit curious, and is the one glaring deficiency of this work. Unlike his GOP predecessors, Reagan actively pushed a fundamental reordering of domestic priorities. It would be instructive to know whether his use of the veto was atypical compared to other Republicans as well as Democrats.

Watson differentiates "significant" vetoes from the rest and classifies that subset by president and such variables as their party, previous elective 
office, partisan control of Congress, presidential support scores, year of term, approval ratings, and "nature of the times" (to gauge the economy and warmaking). All of these predictors are then combined in multiple regression models to determine which factors are associated with veto usage. What I found interesting is that divided government is NOT the main reason for vetoes, though that finding may have been an artifact since he did not include the Reagan-Bush years (the regression for 1953-1981 indicated that 74 percent of the vetoes were accounted for by three variables: presidential "support" score, congressional or presidential election years, and inflation rate). Afterward he gives a classification of vetoes by policy area.

Chapter 3 assesses the impact of executive branch agencies on the decision-making process. Watson chronicles the evolution of the advisory system since FDR. Despite party turnover in the presidency there has been general continuity in the process by which the executive determines whether or not a bill should be vetoed. However, the OMB has lost its monopoly role in this process to White House operatives. Then Watson gives a simple but revealing quantification of the recommendations by OMB, the "lead" (directly affected) agency, and non-lead agencies. After all is said, presidents most often follow the OMB recommendation.

Others who try to influence the veto decision are evaluated in chapter 4: members of Congress, state and local officials, party and campaign leaders, and the public. This treatment is entirely anecdotal. Chapter 5 then focuses on the veto message, beginning with the Framers' intent (to protect the executive from legislative encroachment, unconstitutionality, and unwise policy) and other reasons cited by later presidents (administratively unworkable or fiscally unsound). The subset of significant vetoes are analyzed with those five categories, and also by president, party, and policy area. Then the "unwise policy" category is specified in more detail in order to determine that most presidents object to bills which disadvantage a particular group or interest. Watson proceeds to tabulate the override attempts and, what is more significant, to ascertain for each president and policy area whether new legislation later was enacted and, ultimately, which branch prevailed. These data indicate a draw, with each branch victorious about one-third of the time and with compromise reached in 34 percent of the cases.

Chapter 6 covers old ground-the item veto, discussing the legal issues and the latest (of ongoing) attempts in Congress to clarify the use of impoundment "rescissions" as a more acceptable alternative to the item veto. In his concluding chapter, Watson makes known his belief that the Founders "made a wise choice in deciding on a qualified veto and vesting it in the president alone" (p. 189), as well as his opposition to altering the veto because "[r]ather than serving as an instrument of fiscal restraint, the item 
veto would much more likely become a political weapon in the hands of the president" (p. 193). Furthermore, says Watson, the pocket veto ought to apply only at the end of the entire two-year Congress, not during other recesses or adjournments, and the practice of recent presidents (seemingly most were Republicans) of "signing statements" to restrain the impact of legislation is not constitutional.

Presidential Vetoes and Public Policy is both a fitting tribute to one of our better known colleagues (Watson is now professor emeritus at the University of Missouri) and a paradigm for the use of eclectic methods rather than any one approach when doing policy research of this kind. It is beautifully written but, more important, Watson blends the historical account with documentary research from presidential libraries, adds legal precedents, and includes statistical analyses (what will prove to be the original contribution of this work) to address the issues of how, why, and under what conditions presidents have exercised the veto power.

Raymond Tatalovich Loyola University, Chicago

Cook, Elizabeth Adell, Sue Thomas, and Clyde Wilcox. The Year of the Woman, Myths, and Realities. Boulder, CO: Westview Press, 1994. 276 pp. (\$49/95 cloth, \$14.95 paper).

The Year of the Woman is a welcome addition to the study of women in politics. For much too long there have been few in-depth analyses of the role of women in the political arena. Prior research has failed to explain as well why there are so few women in politics; rather it has focused on mass political behavior and attitudes of women.

In addition to a thorough study of women during the elections of 1992 , the authors have attempted to explain the reasons for gender differences and changes now occurring nationwide. By intertwining sociological implications with political theory, a broad spectrum of concerns are addressed in this timely publication.

Based on the authors' premise that the "1992 election represented an important change from the pattern of incremental gains by women candidates throughout the 1980s," readers must also understand that some of the factors which created those gains seldom occur. Was this success a fluke, or has real change occurred in the attitudes of voters? Chapter 1 successfully answers this and other questions explaining women's gains in 1992. 
Chapter 9, a comprehensive study of "Political Parties and the Year of the Woman" by Robert Biersack and Paul S. Herrnson, fails to stress the importance of women as party leaders. Men have shared an "Old Boy network" for years. But women are only beginning to form their own "network, " primarily due to their party leadership positions. Political parties often provide initial participation and access to the political system. Parties may also introduce women to influential individuals and institutions that can further their campaigns and candidacies by providing services and funds. The question remains whether parties should recruit and nominate women just because they are women, or should they seek the best qualified candidate to carry the party's banner?

By exploring diverse aspects of politics such as campaigns, political parties, PACs, and the media in the final chapters, in addition to specific case studies of the 1992 elections, this study greatly enhances our understanding of women as participants, candidates, and voters. As an insightful text for gender studies or political science courses, future participants and candidates will be well-served by studying this scholarly, well-researched information.

Although this text does not attempt to focus on the broader issue regarding women's mass-level participation, it does address the question that one reason more women are not elected is that fewer women than men consider themselves for public office. And does it matter whether more women are elected to public office? The answers to these questions provide additional insight to future elections. Then 1992 will not be "The Year of the Woman," but rather the beginning of equality and parity in the political arena. The understanding that can be gleaned from the analyses in this new text is welcome, and will encourage and assist all women in future elections.

Toni Phillips

University of Arkansas, Fayetteville

Witt, Linda, Karen Paget, and Glenna Matthews. Running as a Woman: Gender and Power in American Politics. New York: Free Press/Macmillan, 1994. 330 pp. (\$22.95 cloth).

Running as a Woman is required reading for those interested in women and politics. Journalist Linda Witt, in collaboration with political scientist Paget and historian Matthews, provides detailed coverage of American women's campaign experiences, strategies and voting patterns from the late 1880 s through the 1992 elections. Although more descriptive and anecdotal 
than theoretical, the authors' interdisciplinary approach produces an excellent resource for the study of women's campaign politics. The inclusion of information from interviews with female candidates and officials, consultants, and political scientists, as well as the coverage of women's organizational meetings, enhances more typical analyses of polling data, historical accounts and election results. The authors contend that the 1992 elections show a clear impact of the women's vote, particularly for women candidates. They attribute the unusual success of women candidates in 1992 partially to the mobilization of women after the Anita Hill case. The outrage over Hill's treatment by an all male Senate committee altered previous voting patterns in which women were not likely to vote for a candidate because of her gender or "women's issues." Although the authors do not suggest that the Hill effect necessarily will continue, they document the significant increase in political donations by women, and to women-candidate PACs, as well as the significant increase in the number of women running for office and winning.

In addition to their examination of factors particular to the 1992 elections, the authors differentiate these election specific factors from those trends and factors which have been developing over the past twenty years. Finally, they attempt to place these trends into a long-term historical context.

Ruth Mandel, Director of the Center for the American Woman and Politics, called the 1992 elections "a revolution . . . twenty years in the making." Mandel cites the anti-incumbent sentiment, along with reapportionment, as creating the potential for more turnovers in Congress in 1992 than anytime since 1948. Jane Danowitz, head of the Women's Campaign Fund, contends that "opportunity met readiness." The work of the National Women's Political Caucus, the National Organization of Women, Emily's List, WCF and other current and past organizational efforts promoting women candidates during the past twenty years are described as steadily improving the viability and credibility of women candidates.

The most daunting barrier women had to overcome to be "ready" for the 1992 opportunities was the doctrine of coverture, under which the legal status of women was determined by their spouse or male family members. Although portions of that doctrine have been altered under the law (excepting restrictions on the rights to an abortion), Witt, Paget and Matthews contend that two fundamental cultural and economic consequences of coverture inhibit women's political involvement: financial independence and the stature necessary to the exercise of public leadership.

One of the cultural bases for coverture was the assumption that women were "different" from men in significant ways. Until recently, such 
differences were considered as liabilities for women seeking office. As antiincumbent sentiments and political cynicism have grown, however, women have begun to benefit from the perception that they have a "different voice" than men, which offers greater honesty, compassion, responsiveness and change. This was particularly evident in the 1992 elections.

Running as a Woman does not paint the twenty years of increasing readiness as easy ones for women candidates or their supporters. Nor would the authors suggest the difficulties facing women candidates are over. Coverage begins with women's participation in voluntary or charitable organizations in the late 1800 s, followed by suffrage and peace movements and the beginning forays into office holding.

In women candidates' own words, Running as a Woman traces women's efforts to fight discrimination and stereotypes within their own parties, their struggles to combine family and political roles, and their debates with consultants and political leaders about how best to present their candidacy to the public. The authors examine how women candidates relate to the press and address the fact that women are treated differently than men in media coverage. They discuss the many defeats and the few victories. In their final chapter, they discuss the differences women have made as incumbents.

Obviously women candidates are not the only ones attempting to influence the women's vote. Running as a Woman provides a credible examination of patterns in the women's vote, as well as the efforts of various campaigns to manipulate it. Detailed coverage of the 1980-1992 presidential campaigns, for example, illustrates both the greater competency of Republican strategists in the 1980 s and the complexity of "sub-gender" patterns. Eleanor Smeal is credited with "creating" the gender gap phenomenon, but survey data have never suggested that the gap is related to Smeal's feminism. Age and economic status are only two of many variables that interact with the dominant campaign issues to influence women voters. The analysis of the 1992 data in Running as a Woman would caution those who treat women as a single voting bloc.

Running as a Woman gives more attention to legislative and congressional races and candidacies than to executive races and governance. While this emphasis reflects the reality of women's experience thus far, it suggests that the gender neutral political environment that the authors and others envision is not close at hand. 


\section{Political Theory}

Jung Min Choi and John W. Murphy. The Politics and Philosophy of Political Correctness. Westport, CT: Greenwood Publishing Group, 1993). pp. xiv, 168. (\$68.95 cloth).

The phenomenon of "political correctness" - the mostly academic movement to revamp our discourse and educational curricula by removing stereotypical, offensive and "disabling" language-is in dire need of investigation and explication. As a doctrine that has inspired fervent proponents and ferocious critics, all claiming to defend the values of democracy and freedom, it raises many interesting questions, some of which this book attempts to answer. Unfortunately, this unevenly written, unambitious volume provides relatively few solid, thoughtful answers to the questions it does address, and fails to come to grips with those of a deeper nature.

Choi's and Murphy's intent "is to move the discussion of PC to a new level" by accurately characterizing its philosophical foundations and normative prescriptions. This defense of political correctness, the authors believe, will allow the public to make a fully informed choice between the goals of this doctrine and those implied by its opponents, by moving the level of debate beyond the "exchange of barbs." Their main argument is that the popular, hostile portrayal of political correctness is misleading in accusing PC of incompatibility with democracy and freedom. Rather, they contend that political correctness is "really" the doctrine most congenial to those values, while its opponents (exemplified by Dinesh D'Souza and Allan Bloom) are nothing more than Burkean conservatives.

The larger argument depends upon an initial, undocumented equation of political correctness with deconstruction and post-modernism. Instead of providing a rigorous explication of the possible textual links between political correctness and post-modernist philosophy, Choi and Murphy furnish a set of mushy, unsupported claims such as: "While PC is not synonymous with post-modernism, they are associated because of their respective positions of the interpretive or non-dualistic character of reality. Therefore referring to PC as the postmodern alternative is somewhat justified" (p. 57). What follows is an almost total conflation of political correctness with postmodernism, for the conflict between postmodernist philosophy and "realist" views is the main subject of discussion in chapters 2,3 and 4 . The reason for this conflation (aside from the unexamined equation of Stanley Fish with political correctness) may be the "conservatives'" own association of political correctness with postmodernism. A thorough response to the doctrine's critics would have to take this linkage seriously, especially if the 
aim is to best those critics on their own field. Yet one need not and should not accept the conservatives' position uncritically. Not only might the equation be wrong; its easy acceptance also blocks one from asking basic, important questions about the connection if it does hold: is political correctness inextricably tied, and/or an inevitable political outcome of postmodernism as a philosophy? And, as a political position, does it exhaust postmodernism's critical energy?

Choi and Murphy do a somewhat better job of analyzing the debate between adherents of postmodernism and conservative (political and cultural) foundationalism. Although it is unsystematic and all too brief, they provide a convincing argument that D'Souza's and Bloom's kulturkampf, as well as foundationalism's "reality"-based critiques of postmodernism in general, are not as politically neutral as they claim. Equally persuasive is their argument that postmodernism's emphasis on multiple interpretations of reality need not be totally incompatible with a kind of order.

Yet, on a deeper level the bulk of this book fails to satisfy, because it neglects to address seriously the larger questions surrounding political correctness and the current reactions to it. Is postmodernism or foundationalism the better philosophical position, not only from which to define and extend democracy and freedom, but also to defend them? Must political foundationalism (for example, in the form of constitutionalism) inevitably result in a conservative privileging of a particular political culture, or is that a trait peculiar to the Burkean foundationalists now attacking political correctness? Can the proponents of political correctness and cultural foundationalism ever be reconciled (or the latter "tolerated" by postmodernism)? Is either outcome a laudable goal from the PC point of view? Choi and Murphy spend so much time defending political correctness against "distortions," and defining what it is not, that they neglect such larger problems and furnish only a cursory (because often irritatingly smug and simplistic) case for why we should be interested in the doctrine.

This problem is especially apparent in the (ironically) one-dimensional and taken-for-granted nature of the descriptions and political values Choi and Murphy employ. On one hand we have appeals to "social reality" (from defenders of multi-interpretiveness!), and the standard of making institutions "compatible with human actions" (All? If not, which ones?). On the other hand we are asked to accept the question "Yet how can society be too democratic?" as if the question was rhetorical and the answer unproblematic. But one need not be a cultural conservative to ask whether there might be rules or standards we would not allow majorities to change, or to recognize that freedoms might clash. For all the invocations of Fish's assertions that order, democracy and freedom can characterize a society governed by 
postmodernist values, this reader would require much more explanation, analysis and evidence to be convinced of the overall superiority of a postmodernist and politically correct order.

In sum, this book is a laudable attempt to come to grips with an important subject. Its strengths lie in its ability to explain clearly postmodernist philosophy, explain the consequences of the conservative position, and puncture inflated conservative criticisms. Its weakness lies in its inability to pose and answer the larger questions implied by the debate (especially with regard to the nuances necessary to extending and preserving freedoms), and its failure to make us care for political correctness at any level beyond pity for an unjustly maligned school of thought. Unfortunately, this could have been a larger, more ambitious, and therefore better and more useful book.

David Lorenzo

University of Arkansas, Fayetteville

Rideout, Walter B. The Radical Novel in the United States: 1900-1954. New York: Columbia University Press, 1992.339 pp. ( $\$ 29.00$ cloth, \$13.95 paper).

There is good news and bad news about this book. The good news is that Columbia University Press is republishing a long-out-of-print gem. The bad news is that the book has not been revised to bring the odyssey of American radical fiction up to the present. We are treated, however, to a new introduction by the author where he reflects on criticisms of the original publication and on the current state of society, so different from the one which spawned the radical literary tradition.

Rideout's book is a valuable and original contribution to the debate about the relationship between popular culture and politics. His distinction between the "radical" and "social protest" genres is a helpful way of differentiating two related literary traditions. Social protest novels bring critical witness to radical change. Steinbeck's In Dubious Battle and Sinclair's The Jungle are among the best examples in this tradition: radical rhetoric; overthrow of the existing system. According to Rideout, London's The Iron Heel and Mailer's The Naked and the Dead stand among the best examples of this type in the American tradition. Although concentrating on the radical tradition, the author's discussion frequently makes reference to the much more prevalent (within American literary tradition) protest tradition.

Rideout's fundamental thesis is that the radical novel in America has been a function of specific political and economic conditions and circum- 
stances. It has flourished in times of social conflict and economic deprivation. It has waned in times of official oppression, war, and "relative" prosperity. The tradition was born in the wake of the dashed hopes of 19th Century Progressivism. In the 1890s and the first decades of the 20th Century, it depicted struggle between a rising labor movement and private privilege. The ideological underpinnings, historically derived from The Communist Manifesto and Capital, were nurtured in the activities of "Big Bill" Haywood's Industrial Workers of the World, the American Socialist Party and The International Socialist Review. The radical literary movement was prominent again in the 1930s, stimulated by a romantic vision of the great Soviet experience and the uncertain misery of world-wide depression. While few American writers were Communists or fellow travelers, many were nevertheless mesmerized by the transformative imperative of the great empire in the east.

On the other hand, the radical tradition declined after World War I, in part because of the chilling effect of official persecution of radicals and also as a consequence of the illusory prosperity of the 1920s. Rideout documents a similar pattern after 1940 . To be sure, the widespread disillusionment of the leftist tradition with the reality of Stalinism explains some of the decline. Much, however, stemmed from the relatively good economic times throughout the 1940s and the growing pressure on the arts and letters during the McCarthy era, and the general inhospitality of the Cold War period-it is never safe to be a radical when one's country is on war-time alert, hot or cold.

Rideout observes that the radical literary tradition was rarely blessed by good writing. Nevertheless, the radical novel played an important role as a passionate reminder of the inequities and injustices inherent in modern industrial societies. He rightly suggests in his 1992 introduction that a rereading of The Radical Novel might stimulate greater willingness to speak out "against bad government, economic oppression, social injustice of any kind as one way to arrest national decline." In that conclusion I heartily concur.

I also conclude that it might be interesting to follow the threads of the radical tradition into the present. While the "proletarian novel" is no longer in fashion, I wonder if the radical (and social protest) tradition has not continued in the new strains of fiction by black, hispanic, feminist and other authors, responding in protest to America's most unpopular war, Vietnam. Indeed, it would be fascinating to contrast the styles and impacts of minority writers of the past such as Richard Wright (whom Rideout identifies with the radical tradition) with more recent ones, such as Chester Himes, whose 
angry (and, yet very humorous) Harlem prose would place him squarely in the same tradition.

Steven M. Neuse University of Arkansas, Fayetteville

Stetter, Edward A. Shaping Modern Liberalism: Herbert Croly and Progressive Thought. Lawrence: University Press of Kansas, 1993. 225 pp. (\$29.95 cloth).

By 1920 the American progressive movement had given rise to a "new liberalism." The new doctrine sought to maintain classic liberalism's concerns for civil liberties while rejecting laissez-faire economic theory in favor of a democratically regulated economy. This book analyzes the political theory of Herbert Croly. Croly struggled, first as a progressive and later as a liberal, to reconcile within democratic society the competing imperatives of strong national governance and individual rights. Stettner's in-depth examination demonstrates the important contribution Croly made to the evolution of the "new" liberal thinking.

Croly was forty years old when his first major work of political theory, The Promise of American Life, was published. The years preceding that work are the subject of Stetter's second chapter. Croly's parents were both journalists. While the extent to which Herbert adopted the particular political views of his parents is unclear, growing up in such a family must have played some role in his decision to pursue a career as a political writer.

Croly began his Harvard education in 1886 , yet did not complete his B.A. degree until 1910. By the time Croly was awarded his B.A. he had written The Promise of American Life and was already a prominent political commentator. The content of The Promise of American Life is the focus of Stettner's third and fourth chapters.

In The Promise of American Life, Croly calls on Americans to reject the popular idea of "Manifest Destiny" in favor of "promise" and "purpose." If the United States was to have a bright future, that "promise" would not come about without purposeful national planning. Citing corruption in business and politics, Croly explicitly attacked the defenders of the American laissez-faire tradition as protectors of "a religion of personal profit" (The Promise, p. 20). While Croly claimed to be blending nationality and democracy, following Hamilton and Jefferson, Stettner points out that Croly clearly favored the former over the latter. Croly's desire for a national common purpose led him to hold Hamilton in high esteem. 
Croly's national democracy in The Promise combined progressive optimism regarding the modern administrative state with a call for strong leadership from the chief executive. Croly's ideal political leader was Theodore Roosevelt. Despite Croly's call for reliance on a strong leader, Stettner points out (p. 49) that executive empowerment is defended by Croly as necessary for the realization of the public welfare. Further, Croly's nationalism is not devoid of individualist considerations. In fact, his brand of democracy sought to empower the working person; i.e., "to make the individual workingman more of an individual" (The Promise, p. 416).

Croly's second book, Progressive Democracy, was published in 1914. While this work continued to press nationality and democracy, Croly's new work was more strongly committed to democracy (p. 92). Stettner's fifth chapter explains Croly's new emphasis. Croly was optimistic about the potential for direct democracy through the use of initiatives, referenda, and recalls. The new reality of mass-circulating newspapers made these devices more attractive as tools for bringing about progressive reforms.

In the same year that Progressive Democracy was published, Croly became the founding editor of the New Republic. By 1916, the progressive movement essentially had ended, and Wilson had been elected President. As editor of The New Republic, Croly had begun to praise the Wilson administration for its many successes at instituting progressive reforms. However, Croly's satisfaction with Wilson and developments in American politics generally did not last long.

The conclusion of the Versailles Conference resulted in Croly withdrawing his support for Wilson, and ushered in a period of disillusionment in Croly's own thinking about American nationality and liberalism. In Croly's mind, Wilson had agreed to a punitive peace in Europe. The President, according to Croly, had succumbed to the public mood of patriotic fervor and abandoned his earlier, more reasonable commitment to "peace without victory" (p. 129). Domestically, the end of the war saw American nationalism producing an illiberal atmosphere of intolerance. The "Red Scare" of 1919 and 1920 was used to justify censorship under the Espionage Act in the Abrams, Schenk, and Debs cases. Such events led Croly to conclude that his earlier confidence in executive leadership and the capacity of the public to act democratically were in error.

In the end, Herbert Croly rejected politics. Stettner's eighth chapter, "Liberalism in an 'Age of Normalcy'," describes Croly's search for the proper principles to guide state action (p. 149). These, Croly thought, would provide the foundations for liberalism. His search led him to explore the possibilities of self-consciousness. In an unpublished manuscript entitled The Breach in Civilization, Croly pressed the need for religion to play a role in 
social reform. Stettner suggests that what Croly was after was a method that might help liberals in "their own personal conscious effort to lead a good life" (p. 150). Croly never fully developed the connection between religion and the need for liberalism to establish foundations based on individual selfconsciousness.

Stettner's analysis of Croly is thorough and insightful. The book is timely, as well. Croly's work is interesting not only because it helped alter the face of American liberalism but also because it ultimately led him to the search for foundations. This, of course, is the focus of much contemporary writing about liberalism.

Aaron Knight

Texas A\&M University

Strum, Philippa. Brandeis: Beyond Progressivism. Lawrence, KS: University Press of Kansas, 1993. 228 pp. (\$25.00 cloth).

Theodore Lowi argues persuasively in The End of Liberalism that the Supreme Court is the nation's political theorist, developing doctrine, educating the public, and guiding the nation. If Lowi is right, it makes sense to investigate the political thinking of one of the Court's most revered members, Louis D. Brandeis, as Philippa Stern ably does in Brandeis: Beyond Progressivism.

The aim of the book is not to review Brandeis's life experiences, but to analyze his political thinking. But because Brandeis's thinking grew out of his experiences, as opposed to anything he read, the explication of his thought requires retracing his life. As Strum writes, "To see how his ideas developed may be to understand why they took the shape they did" (emphasis in original, p. 6). Each chapter treats an aspect of Brandeis' thought. The range of chapter topics reflects the breadth of his interests: the proper form of economic organization; the role of the law, lawyer, and judge in a democratic polity; the "curse of bigness;" the nature of zionism; the scope of and relationship between civil and economic liberties; and the relationship between the individual and the democratic state. These chapters are preceded by a discussion of Brandeis's early ideas and their relationship to his early life.

What emerges over the course of these discussions is a clear picture of Brandeis' guiding philosophy. Strum identifies his two most basic commitments, to individual development and the primacy of experience as a way of learning, and details their impact on all of the topics she investigates. Brandeis believed that individuals could only reach their full potential in a 
community, and that membership in a community brought with it responsibilities. These responsibilities were not to be shirked: they were opportunities for growth and learning. Indeed, he remained committed to the power of education via experience as the means to realize individual potential. And experience would be most meaningful in small units-small communities, local government, and small business enterprises. From this dual commitment to the individual and experience springs Brandeis' understanding of the unavoidable connection between political and industrial democracy. To fully value the individual requires no less, and industrial democracy would provide the necessary experience to fully realize political democracy. His belief in experience as the optimal educator reveals a healthy dose of pragmatism: he argued that theory without experimentation was meaningless. Thus, his basic commitments and their corollaries fit neatly into one another. As Felix Frankfurter once remarked, "'To quote from Mr. Justice Brandeis' opinions is not to pick plums from a pudding but to pull threads from a pattern.'" (p. 98).

Missing from Brandeis' thinking, and carefully noted by the author, are his blindspots: racial and gender equality (pp. 141-142). Coverage of his inconsistencies, such as his on-the-bench commitment to judicial restraint in contrast to his off-the-bench behavior, make Strum's rendering more fully textured and detailed. Brandeis emerges fully drawn, and Strum avoids the pitfall of overlooking what one might consider the warts and blemishes of her subject, leaving her account all the more credible.

Strum's account yields insights into the impact of Brandeis' life experiences on his political thinking and, not unimportantly, the impact of his political thinking on his actions. For example, it explains his early votes in support of New Deal programs. While Brandeis opposed the New Deal on the grounds of bigness, he favored the experimentation it represented and his commitment to judicial restraint argued for deference to the legislature. These considerations outweighed his opposition to centralization. Strum's treatment also highlights the contrast between Brandeis and other political thinkers, notably Oliver Wendell Holmes, and his impact on other political figures, such as Woodrow Wilson and FDR.

This cogent analysis would benefit from three additions. First, a biographical timeline of the major events in Brandeis' life would be a boon to the reader. Second, given the focus on Brandeis as a political thinker, fuller treatment of his Supreme Court opinions seems justified. And, finally, the author might do more to link the analysis to the subtitle. References to progressivism are infrequent and scattered, and yet the subtitle would seem to indicate the importance of this school of thought to an understanding of Brandeis' thinking. 


\section{4 | Political Theory}

Strum effectively demonstrates the applicability of Brandeis' thought to present day political discourse. Indeed, one leaves the book with a measure of hope, given that a man so deeply committed to experience as a teacher could remain during the course of his life a firm believer in the potential of the common person.

Patricia R. Pauly University of Kentucky 